\title{
MAJOR ISSUES FACING ACADEMIC DEPARTMENTS OF ANAESTHESIA IN CANADA*
}

\author{
EMERSON A. MOFFITT
}

The DePartments of ANAESTHEsia in the 16 faculties of medicine in Canada are at a crossroads. The direction we collectively take now will determine the health of the specialty, perhaps even its survival, for the foreseeable future. In fact, an attempt to decide the proper direction and to move together down the best road, resulted in the formation of the Association of Canadian University Departments of Anaesthesia (A.C.U.D.A.) in $1976 .^{1}$ By an organized, collective effort, we hope to strengthen our departments.

\section{What are our problems?}

The relatively unhealthy state of academic anaesthesia in Canada is evident from the inordinate number of resignations of chairmen last year, temporary chairmen and staff shortages in some departments. Running, or even being in, an academic department has not been in favour recently.

Also, until the last year or so, there have been too few doctors entering our training programmes to come close to supplying the service needs of the country. ${ }^{2}$ A nother significant detrimental factor is the increasing number of academic anaesthetists leaving Canada.

Most of the academic departments are woefully weak in time, money and staff engaged in research, basic of clinical. Too few staff have the interest, background or financial support to do other than clinical work.

Rigg and Harries ${ }^{3}$ dealt at some length with the problems of our specialty in Canada. They saw as a major reason for inadequate recruitment, that anesthetists are perceived by medical students to fill a "secondary technical role". In Canadian departments of anaesthe sia there is a direct correlation between the length of time that medical students spend in a department and recruitment into residency training.

*Paper presented at the Canadian Anaesthetists' Society Conference On Health Economics, Toronto, Ontario, November 11, 1977.

Emerson A. Moffitt, M.D., Professor and Head, Department of Anaesthesia, Dalhousie University. Address: Victoria General Hospital, Halifax, N.S.
Anaesthetists themselves need to feel a greater sense of satisfaction in their careers and this must be evident to potential candidates for training. Rigg and Harries ${ }^{3}$ felt that greater involvement in preanaesthetic care would contribute toward this end.

\section{Surveys of departments}

In 1974 and again in 1977, surveys of all 16 departments of anaesthesia were completed by questionnaire before and just after the formation of A.C.U.D.A. Statistics on the mode of operation of each department were gathered, relative to staff numbers, budget, teaching programme, research activities and funding. While the whole of the 1974 survey is not pertinent here, the following summary related to university departmental financing is useful.

A few departments received reasonably adequate funds to carry out their academic functions of teaching, research and administration. Most departments had inadequate funding to do this and a small number received too little to allow any perceptible academic activity. The latter were simply clinical service groups in university hospitals.

Some departments had an entirely full-time staff on salaries, most of which came from their clinical earnings. In most departments the greatest source of income for the staff was their own clinical earnings.

Almost uniformly there was too smal] a budget of university money to allow full development of academic pursuits. Few departments had funds to pay part-time staff for university work which took time away from their clinical practices.

Six departments indicated that no fee-forservice income was channelled through the university department for academic purposes. In ten departments a small portion of clinical earnings went to the department in a variety of ways.

Seven department heads felt that the incomes of full-time and part-time staff were competitive with those in community hospitals; eight did not.

A wide variety of ideas were expressed as to the ideal financial arrangement between private practice and academic anaesthesia, so that reasonable incomes could be assured for all. In 
summary, most department heads voiced some variation of the same theme: there should be relatively equal incomes for all in a department, regardless of the mix of practice, teaching, research or administration. All aspects but clinical practice should be a financial responsibility of the university.

When asked if their fee-for-service staff looked favourably on teaching and research, to the point of support or subsidy, the answer was "No" in six departments, unqualified "Yes" in two and a qualified "Yes" in five. Three offered no opinion.

Surprisingly, 13 department heads expressed reasonable satisfaction with the size of their university budget, possibly due to a high degree of pessimism as to getting more money.

As to methods of charging clinical fees, group practice alone or in combination was the mode in 13 departments. Two departments operated with independent anaesthetists, and, in one, the university collected the fees and provided salarics.

By 1977 the funding situation had improved slightly in Canadian departments, as a general conclusion. There were still terribly poor ones that were barely surviving.

Relative to adequacy of staff numbers and satisfaction with teaching programmes, there seemed real improvement. Research support and involvement had not changed significantly. One bright ray of optimism is evident: in 1977 and 1978 there are more Canadian graduates entering all the training programmes. Many of the departments have all their residency posts filled with high quality doctors. There seems to be a greater trend than ever before, for new and recent graduates to choose anaesthesia as a career.

\section{Essentials of successful funding of a university department}

From the opinions of 16 department heads, expressed in two surveys and the author's perception of the problems of academic departments, a formula for success can be put forward.

The conditions essential to developing a strong academic department in the responsibilities of teaching, research and administration, along with clinical service, are:

A. Income from clinical services will be the greatest proportion of the total income of a department. Since most of the staff spend most of their time practicing anaesthesia, they support themselves in this aspect of the department's function. Indeed, the clincial service portion is and is likely to remain the largest commitment of staff time. Clinical practice is the basic reason for existence of a Department of Anaesthesia. Teaching, research and administration are essential but take less time, as a portion of the whole.

It appears to be critical that all university staff be in some form of group practice, with no separate, independent anaesthetists. The department head must have control of all clinical earnings and control of appointments of staff to university hospitals, or the head has no control at all.

There can be a department consisting entirely of full-time university staff, with the fees going to the university and back as salary with ceiling. More prevalent in Canadian universities are departments with a proportion, even a majority, of part-time staff, the remainder being full-time staff.

Another necessary factor is an incentive, usually financial, for hard work and productivity. This applies both to full-time and part-time staff. Assured income with other perquisites such as tenure, with no tie to amount of work done, is the most likely way to saddle a department head with unproductive associates. The incentives may be for more cases done in the operating room, more teaching or more research, but it must be there.

There is another truism, not present in many departments, which to me is absolutely critical to a healthy department; that is, there must be sufficient staff to be able to do all the clinical anaesthesia without depending on residents. Not that the staff should do all the cases but at times the system should be able to function without the trainees. This should happen when the residents go to seminars and other learning activities. The presence of residents for their necessary experience allows staff time for pursuits other than clinical service.

B. Income from clinical practice should not be expected to subsidize the academic responsibilities of a department to any appreciable extent. Both part-time and full-time staff object to much of their earnings paying for teaching and research.

But everyone in a department should expect to contribute to some degree to the development of their own department. This can range from donation of time for teaching or committees to contribution of earnings over ceiling. One approach that can be successful is to have a departmental development fund to which staff contribute.

All members of a university department should have an allegiance to that department, if only because they benefit in various ways, compared to working in a non-university centre. One clear benefit is that associated with having residents: 
for call, to teach and for the countless things that residents do. Less overt but still significant is the prestige and respect accorded to members of teaching departments, whether or not they ever perform anything but clinical service. University staff who disclaim any responsibility to their department, financial or otherwise, are ignoring these benefits. They should not be in a university department.

C. All functions of university departments that are not income producing need to be funded by the university, i.e. the provincial governments. All activities except the clinical practice of anaesthesia are in this category: teaching, research and administration. Each staff member needs to be paid by the university for whatever proportion of his work week is occupied in any or all the aspects of academic work. The remainder of time is in clinical practice and is remunerated from the same source as the non-university anaesthetist.

Hence a department is likely to have staff with a spectrum of proportions of acadernic to clinical work. Some would be nearly full-time teachers or investigators, while at the other end would be full-time clinicians in the part-time category of staff.

A point to be made is that not a large proportion of the total staff need be spending most of their time in teaching, administration and research, to produce a strong department. What counts is the organization, motivation and productivity of those in these endeavours, well supported by the university resources. Probably it is better to have a broad base of staff spending only part of their time in academic work, than a small number fulltime, to the near-exclusion of clinical work. Every member of a department, particularly the investigators, need to spend at least a small part of their time practicing anaesthesia, to retain their clinical relevance and competency.

Part-timers should be paid per hour or per day of tcaching. The career investigator needs his income from the university while his research costs ultimately must be supported by extramural grants.

\section{SUMMARY}

Two conditions must be present for a successful and strong department:

(1) the utilization of operating rooms must be efficient, patient volume must be adequate and turnover rate be rapid, if the clinical income of academic staff is to be equal to that of nonacademic anaesthetists. This is really difficult with the surgical teaching that takes place in teaching hospital operating rooms. But if university hospital operating rooms are not comparably efficient, clinical incomes for academic anaesthetists are not competitive to private practice.

(2) the university (i.e. the provincial government) must pay staff adequately for their academic time so that high-grade people will accept and stay in academic posts. Part-time staff deserve to be remunerated for their contributions, whatever the magnitude, or motivation to do it is minimal.

If these basic criteria of financing a department are fulfilled, development of the academic func. tions will follow. Strong academic departments will be producing the capable anaesthetists to fulfill the manpower needs of our specialty in Canada. If not, more departments will atrophy and the manpower situation for anaesthetists in Canada will be in an acute crisis.

\section{RÉSUMÉ}

Les départements universitaires d'anesthésie au Canada sont à la croisée des chemins. Les décisions et les actions prises maintenant auront des répercussions sur l'évolution à long terme de notre spécialité au pays.

Dans l'ensemble, il n'ont pas eu la vie facile récemment. La perte de plusieurs directeurs de département et une pénurie de personnel professoral en sont les témoins. Trop peu de médecins s'inscrivent dans nos programmes d'entrainement. La plupart des départements n'ont pas suffisamment de personnel pour en affecter à la recherche; il n'ont d'ailleurs pas de fonds sufhisants pour le faire.

Une enquète menée en 1974 auprès des seize départements universitaires canadiens indiquait que la plupart d'entre eux n'avaient pas suffisamment de fonds pour permettre la réalisation adéquate de leurs fonctions d'enseignement, d'administration et de recherche. Certains d'entre eux en étaient pratiquement limités à du travail clinique avec un peu d'enseignement. Une seconde enquète menée en 1977 a permis de constater une certaine amélioration dans le nombre du personnel professoral ainsi que dans la qualité des programmes d'enseignement; du point de vue recherche la situation était inchangée; le nombre de gradués des écoles canadiennes qui se dirigeaient vers notre spécialité était croissant.

Certains pré-requis s'imposent pour voir éclore une vie universitaire active:

(A) Les revenue des membres des départe- 
ments doivent continuer de provenir principalement de la pratique clinique, la plupart d'entre eux y consacrant la majeure partie de leurs énergies. Tout le personnel des départements devrait être incorporé à une pratique de groupe. Les postes hospitaliers universitaires devraient ètre sous le contrôle du directeur du département. La productivité devrait être stimulée par des méthodes incitatives (financières le plus souvent) et ceci dans tous les domaines des activités départementales. Les départements ne devraient pas être dépendants de la présence de résidents pour ètre capables de satisfaire à leurs responsabilités cliniques.

(B) Les membres d'un département universitaire ne devraient pas avoir à subventionner les activités académiques du département par leur travail clinique, du moins, pas de façon importante. Par ailleurs, ils devraient tous se sentir responsables de la bonne marche de leur département. Il est normal que l'on s'attende à ce qu'ils contribuent tous à sa bonne marche et à son épanouissement et ceci, de façon modeste, mème leurs deniers.

(C) Toutes les activités départementales autres que la pratique clinique (enseignement, administration et recherche) doivent être subventionnées par l'université.

Dans le but de favoriser le recrutement d'un personnel de haute qualité et de la conserver, les revenus provenant de la pratique en milieu uni- versitaire doivent étre compétitifs avec ceux trouvés hors de cette pratique. Ceci implique que:

(a) Les salles d opération des hôpitaux universitaires soient aussi efficaces que celles des hôpitaux généraux non universitaires, une chose difficile à réaliser. Pourtant și ce n-est pas atteínt, les revenus ne pourront être compétitifs.

(b) Les gouvernements provinciaux fournissent aux universités les moyens de dëfrayer les coûts des activités non cliniques des départements et cela à des tarifs comparables à ceux reliés aux activités cliniques. Si ce n'est pas fait, le personnel effectuera le travail clinique de préférence.

Si l'on peut satisfaire à ces exigences, l'on pourra développer des départements capables de mener à bien leurs fonctions académiques. Dans le cas contraire, l'on assistera à l'atrophie des départements universitaires et, éventuellement, à une pénurie grave d'anesthćsistes au pays.

\section{REFERENCES}

1. MoffitT, E.A. Academic Anaesthesia Organizes. Editorial. Canad. Anaesth. Soc. J. 25, 1 (1978).

2. Report of the working party on Anaesthesia, for the Requirements Committee on Physician manpower. National Health and Welfare (1975).

3. RigG, J.R.A. \& HarRies, J.D. Future of Anesthesia. Canad. J. Surg. 20, 467 (1977). 